\title{
Research on the Merger and Acquisition of Listing Corporation -A case Study of M \& A Enterprise Knowledge Assets
}

\author{
LiHua Cui ${ }^{1}$, De $\mathrm{Li}^{2}$ andHyeJeong $\mathrm{Kim}^{3}$ \\ ${ }^{1}$ College of Economics and Management, Yanbian University, Yanji, China \\ [2732677@163.com] \\ ${ }^{2}$ Department of Computer Science, Yanbian University, Yanji, China \\ [leader1223@ybu.edu.cn] \\ ${ }^{3}$ Department of School of Business Administration, Kyonggi University, Seoul, Korea \\ [hj5417@naver.com] \\ *Corresponding author: De Li
}

\begin{abstract}
$M \& A$ is an important means for enterprises to achieve the rapid growth and development, is one of the important strategy for continuous operation in the process of company.

$M \& A$ of knowledge assets is a kind of business means of rapid access to core technology and knowledge. More and more enterprises want to strengthen their ability through the $M \&$ A of other knowledge assets of enterprises, to enhance the market competitiveness of enterprises. With the development of $M \& A$ of knowledge assets, the enterprise wants to use the unique knowledge assets to increase the listed company's market performance and improve the financial structure of listed company. This paper draw some conclusions through the study of Chinese listed company which have taken knowledge assets mergers and acquisitions, to help people find some problems in the process of knowledge assets in mergers and acquisitions of listed companies, in order to provide some reference for China's listed companies in the $M \&$ A of knowledge assets.
\end{abstract}

Keywords: $M \& A$, intellectual assets, $M \& A$ performance

\section{Research Hypotheses and Data Selection}

\subsection{Research Hypotheses}

China's listed company is consistent with other listed companies for $\mathrm{M} \& \mathrm{~A}$ of knowledge assets procedure. But because of the uniqueness and exclusiveness of $\mathrm{M} \& \mathrm{~A}$ of knowledge assets, knowledge assets are mostly bought at a premium at the listed company mergers and acquisitions. The invested capital is huge. Effectively, reasonable using knowledge assets can make the enterprises to seize the initiative in the market competition, access to long-term sustainable development opportunities. The process of M \& A by listed company will be supervised by the laws of the country and multiple departments. Whether after the merger of enterprises is to optimize the structure and integrate resources or not, what are important impact factors in the process of $\mathrm{M} \& \mathrm{~A}$. Therefore this paper puts forwards the following hypothesis:

A: Increasing the transaction price is positively related to the increase of shareholder wealth caused by the announcements of M \& A of intellectual property of listed company. 
The study results by Li Shanmin and Ceng Zhaozao (2004) showed that the M \& A paid price can significantly affect the enterprise in performance, and there is a positive correlation between them. Trademarks and goodwill in the modern enterprise has been used as an important intangible asset of enterprises. When $M \& A$ enterprises purchase the other enterprises trademarks goodwill, this project's price of M \& A of knowledge assets is higher than the book value of the target enterprise. That is the difference. If the price is higher than the book value of target enterprise, then the enterprise can get more excess return.

In the process of selecting the sample data, the note of $M \& A$ always marks "purchase price". It views the higher price between the last assessment agencies price and the real price as benchmark. From which we can see the importance of the transaction price in the knowledge assets in mergers and acquisitions, so this paper chooses the $\mathrm{M} \& \mathrm{~A}$ transaction price as one of the variables.

B: Free cash flow is positively related to the increase of shareholder wealth caused by the announcements of $\mathrm{M} \& \mathrm{~A}$ of intellectual property of listed company.

According to the free cash flow motivation hypothesis, the enterprises can improve their operational efficiency, and can bring economic benefits for shareholders in M \& A. Under the same conditions, the more pre-merger free cash flow, the more economic benefits to shareholders. But the problem is that the beneficiary of economic interests is the target enterprise shareholder or the acquisition of shareholder. Maybe these economic benefits will be allocated between the shareholders according to the negotiation ability of different.

As the preliminary due diligence and information was leaked in advance when the Chinese listed company in $\mathrm{M} \& \mathrm{~A}$, it has passed the positive information to the market. And because of the unique nature of knowledge assets, $\mathrm{M} \& \mathrm{~A}$ of knowledge assets will bring substantial free cash flow to $\mathrm{M} \& \mathrm{~A}$ enterprises in the short term.

C: Return on invested capital is positively related to the increase of shareholder wealth caused by the announcements of $\mathrm{M} \& \mathrm{~A}$ of intellectual property of listed company.

J.Kitching (2001) used the rate of return on investment, the growth rate of income and earnings per share of internal financial data easy to judge the success of M \& A. Many scholars have established the multiple index and single index evaluation technology M \& A's performance. Return on invested capital = interest before tax operating profit $/$ capital. This ratio is associated with a capital profit radio, a measure of a using effect of funds. The study of knowledge assets includes patents, proprietary technology, trademarks, goodwill, core talents, and related assets. Uniqueness of these knowledge assets can make them in M \& A enterprise combine their advantage, and make the enterprise in a dominant position in the market competition, and expand market share, increase the profit of the enterprises, can bring high returns to shareholders.

\subsection{Data Selection}

Related information and data that this paper refers to the Chinese listed company merger and acquisition mainly come from the following sources:

1. This paper selects $M \&$ A of knowledge assets events which Chinese listed company notes involves, according to the "China listed company merger and reorganization of the database 2010V" of China Tai'an Information Technology. Note the listed company mergers and acquisitions in the database involves intellectual property content, including technology, proprietary technology, trademarks, goodwill, the related assets, technology backbone personnel, patents, software technology. Select M \& A data in accordance with the above requirements as the primary sample.

2. Financial data on the Sample Firms mainly come from Rui $\mathrm{Si}$ database http://www.resset.cn. 
3. Statistics and analysis of the data was done using SAS8.0 and SPSS18.0 software.

This paper takes the M \& A transaction sample from 2001 to 2010 in the "China listed company merger and reorganization of the database 2010V" of China Tai'an Information Technology as the initial sample.

The following sample selection conditions:

1. Selecting board of listed companies in Shanghai, Shenzhen from 2001 to 2010 years.

2. Involved in $\mathrm{M} \& \mathrm{~A}$ of knowledge assets is ultimately successful.

3. The disclosure of the data and the memo from listed company relate to the patent right, proprietary technology, trademark right, goodwill and other knowledge assets.

4. Except the companies that continuous acquisition more than twice during the analysis of the listed company.

5. Financial listed companies are not included in the sample.

6. Sample data removed partial shares of missing data samples during the study period.

After the above processing, choose 72 cases involving intellectual property acquisitions occurred in 2001-2010 as the final study sample.

In line with the principle of seek truth from facts, use the historical facts and statistics data as the basis for empirical analysis.

\section{Table 1. Introduction of the Industry Distribution of Knowledge Asset Acquisitions of Sample Firms}

\begin{tabular}{|c|c|c|}
\hline code & Firm name & Sample size \\
\hline A & $\begin{array}{l}\text { Agricultural, forest, } \\
\text { animal, fishery }\end{array}$ & 1 \\
\hline B & Mining industry & 1 \\
\hline code & Firm name & Sample size \\
\hline $\mathrm{C}$ & $\begin{array}{c}\text { Manufacturing } \\
\text { industry }\end{array}$ & 52 \\
\hline $\mathrm{D}$ & Electricity, gas & 2 \\
\hline $\mathrm{F}$ & $\begin{array}{c}\text { Transportation } \\
\text { warehousing }\end{array}$ & 1 \\
\hline G & Information technology & 3 \\
\hline $\mathrm{H}$ & Wholesale and retail trade & 2 \\
\hline $\mathrm{J}$ & Realty industry & 3 \\
\hline K & Social service industry & 3 \\
\hline M & Comprehensive & 4 \\
\hline
\end{tabular}




\section{Regression Analysis}

This paper uses the method of event study to do the empirical analysis on the market reaction of knowledge assets merger and acquisition that the stock price changes before and after the listed company $\mathrm{M} \& \mathrm{~A}$ of knowledge assets. But in the performance study of $\mathrm{M} \& \mathrm{~A}$ of listed company, only by changing of the listed company stock price to illustrate the performance of M \& A couldn't reflect the real economic benefits of $\mathrm{M} \& \mathrm{~A}$. The stock price is influenced by many aspects, not only by the listed company $\mathrm{M} \& \mathrm{~A}$ announcement to come to conclusions, such as the market efficiency reasons of mispricing. In order to further study the influence factors of listed company $\mathrm{M} \& \mathrm{~A}$ of knowledge assets, this paper used the cumulative excess returns (CAR) as the dependent variable, and combine multiple financial indicators for regression analysis. In order to express clearly the influence degree and ways of related factors on knowledge assets market performance, this paper choose the following variables analysis based on summarizing the research results of other scholars and combined with the relevant motivation theory.

\subsection{The Dependent Variable}

(CAR): CAR is got through M \& A event study method. It represents the change of stock price before and after the M \& A, reflects the degree of influence to shareholder wealth before and after the M \& A. So this paper chose CAR as the dependent variable that analyzes influence factors of listed company M \& A of knowledge assets. Sun Zheng and Li Zengquan tested 133 large stockholder events for China's listed companies from 1997 to 1999 in 2003. The result shows that, during the transfer of control right, sample listed company shareholders made an average of more than $18 \%$ of the excess proceeds. Many research results show that the cumulative excess returns (CAR) can be expressed in enterprise $\mathrm{M} \& \mathrm{~A}$ behavior or the $\mathrm{M}$ $\&$ A enterprise shareholder wealth value in the short term. This paper chooses the commonly used cumulative excess returns CAR as the dependent variable. This paper distinguishes (-30, $30)(-25,25)(-20,20)(-15,15)(-10,10)$ in 10 different time period to study.

\subsection{The Independent Variable}

(1) Bargain price. In America, "intangible assets" was published in 1994 by ARB24. It takes purchased goodwill as an asset confirmation. Purchased goodwill is the M \& A project that is confirmed when the acquisition of enterprises purchase the target enterprise. That is there has difference between the purchase price and the net assets. When the acquisition price is higher than the net assets, that has the ability to gain excess return for enterprises. Li Shanmin, Ceng Zhaozao (2004) study shows, pay price have a significant impact on M \& A performance. There has a positive correlation between them.

M \& A transaction price takes the transaction price from Tai' an data center "China listed company M \& A of the database" as the benchmark.

(2) Free cash flow. Andrade, Mitchen and Stafford (2001) study shows, cash financing of M \& A can help the M \& A enterprises utilize existing resources to produce huge cash flow, or $M \&$ A enterprises make full use of the resources of the goal enterprise to form an investment opportunity.

Free cash flow is the generation of the business activities of the cash flow, which deducts the balance of capital expenditure. Free cash flow is a financial method, which used to measure the enterprise actual holdings of cash to shareholders.

(3) Return on invested capital. Many scholars have established the M \& A performance of multiple index and single index evaluation technology, which is consistent with the results of 
the use of return on invested capital to describe the synergistic. Return on invested capital = interest before tax operating profit / capital. The ratio is associated with a capital profit ratio, a measure of use effect of funds. This paper chooses return on invested capital to test whether the M \& A of knowledge assets can bring high returns for the enterprise or not.

\subsection{Control Variable}

According to the related literature, this paper chose the asset scale, the rate of return on net assets (ROE) and the asset liability ratio among the influencing factors of the knowledge asset market performance as important control variables to study.

(1) Asset size. According to Roll, the scale of the enterprise is the most important to the company long-term credit rating variable. In China, enterprise size decides the enterprise level. So many enterprises are more active in $M \& A$, in order to expand the scale of enterprises. Therefore, the company scale is set as the control variable.

(2) Rate of return on net assets (ROE). The rate of return on net assets is one of the important indexes to measure the management level of profitability. Profitability reflects the enterprise management performance, which directly influence the market investors' judgment. According to the management efficiency hypothesis, In order to maintain high management efficiency, enterprises will strip useless assets or business. Therefore, the profitability of the enterprise will have a certain impact on the stock price reaction of $\mathrm{M} \& \mathrm{~A}$ of knowledge assets announcements. So this paper chooses ROE as important control variable to carry on the research analysis. The index is the rate of return on net assets (weighted) in the Rui Si database, which is the net profit divided by the shareholder's equity of the current period.

(3) Asset-liability ratio. The asset-liability ratio is to measure the financial situation of enterprises. The results show that, the debt ratio can play a supervisory role of management, solve the principal-agent problem between shareholders and management, have a certain role in promoting enterprise achievements play.

Table 2. Regression Analysis of Variables

\begin{tabular}{|c|c|c|}
\hline Variable name & Index note & Expected sign \\
\hline Bargain price & M \& A price & + \\
\hline Free cash flow & $\begin{array}{c}\text { Actual holding cash that } \\
\text { enterprise can return to shareholders }\end{array}$ & + \\
\hline $\begin{array}{c}\text { Return on invested } \\
\text { capital }\end{array}$ & $\begin{array}{c}\text { interest before tax operating } \\
\text { profit / capital }\end{array}$ & + \\
\hline Asset-liability ratio & $\begin{array}{c}\text { Asset-liability ratio of M \& A } \\
\text { announcement last year }\end{array}$ & + \\
\hline
\end{tabular}




\begin{tabular}{|c|c|c|}
\hline $\begin{array}{l}\text { Rate of return on net } \\
\text { assets }\end{array}$ & $\begin{array}{c}\text { Rate of return on net assets }=\text { net } \\
\text { profit divided by the weighted } \\
\text { equity }\end{array}$ & + \\
\hline Asset size & $\begin{array}{l}\text { The natural logarithm of total } \\
\text { assets of the previous year's notice }\end{array}$ & + \\
\hline Variable name & Index note & Expected sign \\
\hline Bargain price & M \& A price & + \\
\hline Free cash flow & $\begin{array}{l}\text { Actual holding cash that } \\
\text { enterprise can return to shareholders }\end{array}$ & + \\
\hline $\begin{array}{l}\text { Return on invested } \\
\text { capital }\end{array}$ & $\begin{array}{l}\text { interest before tax operating } \\
\text { profit / capital }\end{array}$ & + \\
\hline
\end{tabular}

In summary, the regression model as follows:

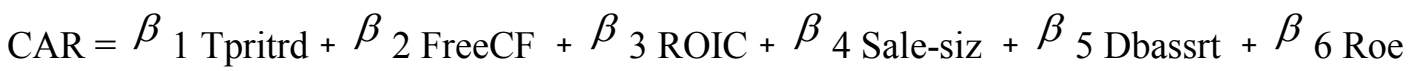

Where : Tpritrd refers to the transaction price; ROIC refers to return on invested capitalSale-siz refers to assets size; Dbassrt refers to asset-liability ratio; Roe refers to rate of return on net assets

\section{The Results of the Empirical Analysis}

\subsection{The Dependent Variable CAR Analysis Results}

The dependent variable CAR is the stock price changes caused by the release announcement by listed company based on the $\mathrm{M} \& \mathrm{~A}$ of intellectual property right. This method is proposed and applied the first time in 1993 by James Dolley in order to study the stock price changes in segmentation. The cumulative returns (CAR) research methods are as following: First, determine the knowledge asset M \& A event window; Second, calculate the sample firms' expected return in the window period, and use sample firms real income minus the expected benefit to get supernormal returns; Third, add the window period of extraordinary returns to get cumulative excess returns CAR.

In this research, event estimation period is from knowledge asset $\mathrm{M} \& \mathrm{~A}$ announcement 300 days $(\mathrm{t}=-300)$ prior to the announcement after 60 days $(\mathrm{t}=60)$. The event window period is before and after the announcement 20 days. In addition, this paper selected the market model method proposed by Sharp (1964) and Linter (1965) that can effectively eliminate the 
overall market factors on the impact of individual securities to calculate the expected return AR.

Table 3 and Figure 1 are the results of the analysis of samples in the window period of knowledge assets $\mathrm{M} \& \mathrm{~A}$ announcements performance.

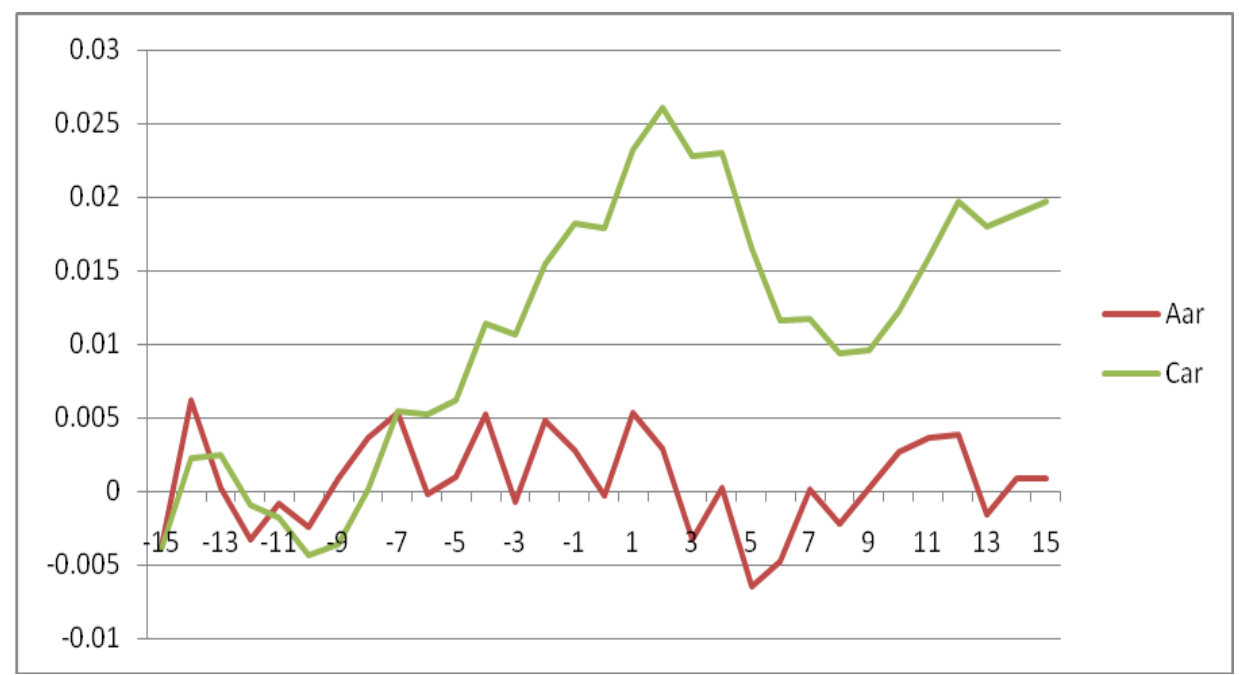

Figure 1.The Excess Returns and the Cumulative Excess Returns of AAR CAR $(-15,15)$

Table 3.Different Window Period CAR and T-test

\begin{tabular}{|c|c|c|c|}
\hline Window period & CAR & Window period & CAR \\
\hline$(-30,30)$ & $\begin{array}{c}0.004993^{* * *} \\
(5.17)\end{array}$ & $(-25,25)$ & $\begin{array}{r}0.009928^{* * *} \\
(2.85)\end{array}$ \\
\hline$(-20,20)$ & $\begin{array}{c}0.019164^{* * *} \\
(4.08)\end{array}$ & $(-15,15)$ & $\begin{array}{r}0.018569^{* * *} \\
(6.76)\end{array}$ \\
\hline$(-10,10)$ & $\begin{array}{r}0.011139^{* * *} \\
(7.34)\end{array}$ & $(-5,5)$ & $\begin{array}{r}0.015354^{* * *} \\
(6.54)\end{array}$ \\
\hline$(-4,4)$ & $\begin{array}{r}0.021874^{* * *} \\
(6.91)\end{array}$ & $(-3,3)$ & $\begin{array}{r}0.021670^{* * * *} \\
(3.92)\end{array}$ \\
\hline$(-2,2)$ & $\begin{array}{r}0.024966^{* * *} \\
(4.89)\end{array}$ & $(-1,1)$ & $\begin{array}{r}0.022081 \\
(2.52)\end{array}$ \\
\hline
\end{tabular}

Note: $* * * * *, *$ says coefficients is significance at $1 \%, 5 \%, 10 \%$ level. 
Figure 1 is the analysis results of sample enterprise's cumulative excess returns in window period $(-15,15)$. Analysis results show that the stock price rises before the $\mathrm{M} \& \mathrm{~A}$ announcement 7 days, and reach the highest values in the announcement day. Many investors believe that the acquisition of intellectual property rights is the good information, buy a lot of stock, which causes the stock price rise situation.

\section{2 .The Results of Regression Analysis}

Table 4. CAR Regression Analysis Results in Different Window Period 1

\begin{tabular}{|c|c|c|c|}
\hline $\begin{array}{c}\text { Dependent } \\
\text { variable }\end{array}$ & CAR(-30,30) & CAR(-25,25) & CAR(-20,20) \\
\hline (constant) & $\begin{array}{c}1.04 \\
(1.068)\end{array}$ & $\begin{array}{c}0.978 \\
(1.121)\end{array}$ & $\begin{array}{c}0.701 \\
(0.858)\end{array}$ \\
\hline Bargain price & $\begin{array}{c}3.741 \mathrm{E}-11 \\
(0.764)\end{array}$ & $\begin{array}{c}4.608 \mathrm{E}-11 \\
(1.049)\end{array}$ & $\begin{array}{c}5.028 \mathrm{E}-11 \\
(1.222)\end{array}$ \\
\hline Free cash flow & $-1.232 \mathrm{E}-10^{* *}$ & $-1.034 \mathrm{E}-10^{* * *}$ & $-1.024 \mathrm{E}-10^{* * *}$ \\
$(-2.412)$ & $\begin{array}{c}(-2.259) \\
\text { Assets value }\end{array}$ & $\begin{array}{c}-0.129 \\
(-1.262)\end{array}$ & $\begin{array}{c}-0.118 \\
(-1.289)\end{array}$ \\
\hline $\begin{array}{c}\text { Return on invested } \\
\text { capital }\end{array}$ & $\begin{array}{c}0.000 \\
(0.032)\end{array}$ & $\begin{array}{c}0.002 \\
(-1.026)\end{array}$ \\
\hline Asset-liability ratio & $\begin{array}{c}0.303^{*} \\
(1.928)\end{array}$ & $\begin{array}{c}0.259^{*} \\
(1.839)\end{array}$ & $\begin{array}{c}-0.003 \\
(0.477)\end{array}$ \\
\hline $\begin{array}{c}\text { Rate of return on } \\
\text { net assets }\end{array}$ & $\begin{array}{c}-0.314 \\
(-1.33)\end{array}$ & $\begin{array}{c}-0.295 \\
(-1.396)\end{array}$ & $\begin{array}{c}0.277^{* * *} \\
(2.095)\end{array}$ \\
\hline
\end{tabular}

Note: 1) $* * *, * *, *$ says coefficients is significance at $1 \%, 5 \%, 10 \%$ level.

2) The CAR unit is $\%$. 
Table 5. CAR Regression Analysis Results in Different Window Period 2

\begin{tabular}{|c|r|r|r|}
\hline $\begin{array}{c}\text { Dependent } \\
\text { variable }\end{array}$ & CAR(-15,15) & CAR(-10,10) & CAR(-5,5) \\
\hline (constant) & 0.679 & 0.567 & 0.539 \\
& $(0.940)$ & $(0.856)$ & $(0.839)$ \\
\hline Bargain price & $5.279 \mathrm{E}-11$ & $4.876 \mathrm{E}-11$ & $-4.038 \mathrm{E}-11$ \\
& $(1.452)$ & $(1.462)$ & $(-1.249)$ \\
\hline Free cash flow & $-7.835 \mathrm{E}-11^{* *}$ & $-7.921 \mathrm{E}-11^{* *}$ & $-7.452 \mathrm{E}-11^{* *}$ \\
& $(-2.066)$ & $(-2.278)$ & $(-2.211)$ \\
\hline Assets value & -0.082 & -0.069 & -0.068 \\
& $(-1.085)$ & $(-0.997)$ & $(-1.008)$ \\
\hline Return on invested & 0.002 & & 0.003 \\
capital & $(0.437)$ & $(0.735)$ & $(0.687)$ \\
\hline Asset-liability ratio & $0.215^{*}$ & & $0.236^{* *}$ \\
& $(1.84)$ & $(1.886)$ & $(2.277)$ \\
\hline Rate of return on & & & -0.164 \\
net assets & -0.241 & $(-1.098)$ & $(-1.051)$ \\
\hline
\end{tabular}

Note: 1$) * * *, * *, *$ says coefficients is significance at $1 \%, 5 \%, 10 \%$ level.

2) The CAR unit is \%.

Table 6. CAR Regression Analysis Results in Different Window Period 3

\begin{tabular}{|c|c|c|c|c|}
\hline $\begin{array}{c}\text { Dependent } \\
\text { variable }\end{array}$ & CAR(-4,4) & CAR(-3,3) & CAR(-2,2) & CAR(-1,1) \\
\hline (constant) & $\begin{array}{c}.519 \\
(.881)\end{array}$ & $\begin{array}{c}.549 \\
(.961)\end{array}$ & $\begin{array}{c}.536 \\
(.950)\end{array}$ & $\begin{array}{c}.544 \\
(.983)\end{array}$ \\
\hline Bargain price & $\begin{array}{c}6.852 \mathrm{E}-11^{* *} \\
(2.309)\end{array}$ & $\begin{array}{c}6.833 \mathrm{E}-11^{* *} \\
(.2 .378)\end{array}$ & $\begin{array}{c}6.959 \mathrm{E}-11^{* *} \\
(2.448)\end{array}$ & $\begin{array}{c}5.537 \mathrm{E}-11^{*} \\
(1.985)\end{array}$ \\
\hline Free cash flow & $\begin{array}{c}-6.257 \mathrm{E}-11^{* *} \\
(-2.022)\end{array}$ & $\begin{array}{c}-5.749 \mathrm{E}-11^{*} \\
(-1.919)\end{array}$ & $\begin{array}{c}-5.248 \mathrm{E}-11^{*} \\
(-1.77)\end{array}$ & $\begin{array}{c}-5.405 \mathrm{E}-11^{*} \\
(-1.859)\end{array}$ \\
\hline Assets value & $\begin{array}{c}-.065 \\
(-1.042)\end{array}$ & $\begin{array}{c}-.066 \\
(-1.106)\end{array}$ & $\begin{array}{c}-.063 \\
(-1.066)\end{array}$ & $\begin{array}{c}-.065 \\
(-1.108)\end{array}$ \\
\hline
\end{tabular}




\begin{tabular}{|c|c|c|c|c|}
\hline $\begin{array}{c}\text { Return on } \\
\text { invested capital }\end{array}$ & .003 & .002 & .002 & .000 \\
& $(.574)$ & $(.389)$ & $(.526)$ & $(.093)$ \\
\hline $\begin{array}{c}\text { Asset-liability } \\
\text { ratio }\end{array}$ & $.196^{* * *}$ & $.160^{*}$ & .144 & .126 \\
\hline $\begin{array}{c}\text { Rate of return } \\
\text { on net assets }\end{array}$ & $(2.056)$ & $(1.74)$ & $(1.576)$ & $(1.414)$ \\
\hline
\end{tabular}

Note: 1$) * * *, * *, *$ says coefficients is significance at $1 \%, 5 \%, 10 \%$ level.

\section{2) The CAR unit is \%.}

Table 4, table 5 and table 6 indicate the regression analysis result that listed company M \& A of knowledge assets market performance factors in different window period. From these regression result data we can see that both the transaction price and asset liability ratio have a remarkable influence on the market performance of listed company intellectual asset merger and acquisition. The asset-liability ratio and the cumulative excess return rate (CAR) have a significant positive correlation; free cash flow is significant negatively correlated with CAR. Asset size, Return on invested capital and Rate of return on net assets have no significant effect on the market performance of listed company intellectual asset merger and acquisition. Thus, we can get the following conclusion:

(1) Transaction price and the cumulative long yields had a significant positive correlation in car $(-4,4)$, car $(-3,3)$ car $(-2,2)$ car $(-1,1)$. Since the majority of listed company intellectual asset price are decided by assessment organization as the acquisition standard, so the listed company intellectual assets mostly are acquisition premium. If the listed company buy target enterprise knowledge assets with high price, then $\mathrm{M} \& \mathrm{~A}$ announcement of knowledge assets will have a certain influence on the share price of the listed company. Price of knowledge assets has not certain rule. Although the knowledge assets is unique, after mergers and acquisitions, that whether the $\mathrm{M} \& \mathrm{~A}$ of enterprises are able to use knowledge assets better or not is uncertainty. The high price will bring risk to knowledge asset merger and acquisition of enterprises on finance. Once the profits cannot be planned withdraw, it will increase pressure on enterprises, and even lead to bankruptcy. Therefore, knowledge assets transaction prices are too high, the information effect of announcement of knowledge assets merger and acquisition are more obvious, and thus market performance of $\mathrm{M} \& \mathrm{~A}$ of knowledge assets are more prominent.

(2) Sample firms' accumulated excess returns CAR and free cash flow in the statistical level of $10 \%$ are significant negative correlation. Namely, the more free cash flow the listed company have, the less effect on the stock price that announcement of knowledge assets merger and acquisition have. If the $\mathrm{M} \& \mathrm{~A}$ enterprise has more free cash flow, then the enterprise has good operation, and all aspects are more perfect. M \& A of other company knowledge assets is just to mark up the lack of certain aspects of the M \& A of enterprises. Even the failure of $M \& A$ has little effect on the enterprise, if the $M \& A$ of enterprises haven't enough free cash flow, that the merger of enterprises more intention is to help enterprises to improve the management condition through unique the knowledge assets, if the failure of mergers and acquisitions probably enterprises will fall into the crisis. Therefore, the more free cash flow, the more obvious the information effect of announcement of knowledge assets merger and acquisition are, and the more prominent that the stock price effects of $M$ \& A of knowledge assets. 
(3) The rate of assets and liabilities and the cumulative excess returns are positively correlated. The higher asset liability ratio of $\mathrm{M} \&$ A enterprise, the lower debt paying ability, and debt capacity is lower. High debt to asset ratio will make the enterprises fall into financial difficulties, and outside financing hard. The listed company passes good news to outside through the $\mathrm{M} \& \mathrm{~A}$ of knowledge assets of other enterprises and the unique knowledge assets. So when high debt level enterprise releases announcement of $\mathrm{M} \& \mathrm{~A}$ of knowledge assets, investors think reasonably using knowledge assets will improve the financial situation of enterprises, and to give a positive reaction.

\section{Conclusions and Suggestions}

\subsection{Conclusions}

Based on the theory of domestic listed company market performance, this paper took released listed companies assets notice in 2001-2010 as sample data, selected 72 listed companies' notice of M \& A of knowledge assets as the final study sample, according to the selection criteria, made an empirical on market performance and its influencing factors of $\mathrm{M}$ $\&$ A of knowledge assets of listed company. China listed company mergers and acquisitions has the tendency to rise year by year; the relevant $\mathrm{M} \& \mathrm{~A}$ of knowledge assets case also increase year by year. China's listed company M \& A of intellectual assets has many cases, including patents, proprietary technology, etc. Although they are specific, unique, market investors for knowledge assets investment have also more cautious attitude, objective, and do not produce the investment blindly.

\subsection{Relevant Suggestions}

(1) Due to the unique nature of knowledge assets make it difficult to find in the market of similar objects as the point of reference, at the same time, Most of the enterprises in the merger and acquisition process as a premium for the acquisition, increase the risk of the purchasing enterprise. It is very important that make the prior investigation to enterprises of M \& A of knowledge assets strategy. And it is an important method to reduce the risk of M \& A.

(2) From the results of short-term performance of mergers and acquisitions of knowledge assets, we can see, as knowledge assets high premium conveys the bad news to the market in the short term, acquisition of enterprises should in advance arrange the funding sources, make sure enterprises in the capital of short-term corporate acquisition strategy smoothly.

(3) From the long-term performance of M \& A of knowledge assets, we can see that after the M \& A, knowledge assets don't bring more interests of shareholders for enterprise in the long term. This is because the uniqueness of knowledge assets makes it different to play a role alone in the enterprise; it must be used in conjunction with other knowledge assets. Otherwise, showing in the kind of environment value may disappear in another environment. This will require the enterprises fully understand the basic knowledge of assets, to create the appropriate external conditions for itself, scientific arrangement of assets structure.

\section{Acknowledgement}

This research project was supported by the National Natural Science Foundation of China (Grant No. 61262090). 


\section{References}

[1] L. H.Cui andH. J.Kim, "Infuen of Overseas M\&A to Company Stock Price in Chinese listed Companies", TY-IMO, (2010),pp. 390-395.

[2] L. H.Cui, Z. F. Piao andH. J.Kim, "Could the EVA Predict Business Insolvency? ", ISAC, (2010), pp. 447450.

[3] L. H.Cui and H. Z. Quan, "Empirical analysis of Chinas listed firms divestitures", AIMSEC, (2010), pp. 7069-7071.

[4] L. H.Cui,"The influence of M\&A information disclosure on the share price", Dongjiang Journal,(2008), pp. 110-112.

[5] L. H.Cui andY.Shen, "An empirical study of how the equity structure of the company influences the management of the performance of the company", Journal of Yanbian University(Natural Science),(2009), pp. 95-98.

[6] L. H.Cui andH. J.Kim, "The effect of the United States financial crisis on east Asia", Dongjiang Journal, (2009), pp. 86-88.

[7] M.C. Jensenand R.S.Ruback, "The Market for Corporate Control: The Scientific Evidence", JFE,vol. 11, (1983), pp. 7-8.

[8] E. M. Kelly,"The Profitability of Growth through Mergers", Pennsylvania State University Univ, Park. Pa.,(1967).

[9] R. Lang, R.M.Stulz and R.A.Walkling, "A Test of The Free Cash Flow Hypothesis: The Case of Bidder Returns", Journal of Financial Economics, vol. 29,(1989).

[10] H. Servaes,"Tobin's Q and the gainsfrom Takeovers", Journal of Finance, vol. 46,(1991).

[11] J. Wansley,W.Lane and H. Yang,"Abnormal Returns to Acquired Firms by Types of Acquisitions and Method of Payment", Financial Management, vol. 38,(1983).

[12] J. Kose and J. Ofek, "Asset sales and increase in focus", Journal of Financial Economic, vol. 37, pp. 105-126.

\section{Authors}

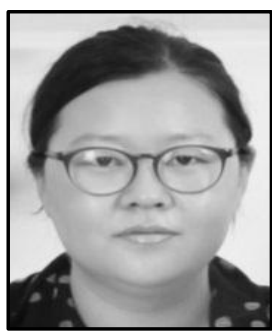

LiHua Cui received the Ph.D. degree from KookMin University, major in Financial Management in 2008. She is currently a professor of Dept. of Financial Management at Yanbian University in China. She research interests are in the areas of business finance, value assessment, merger and acquisition, Engaged in financial analysis.

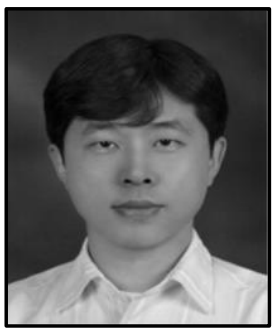

DeLi received the Ph.D. degree from Sangmyung University, major in computer science in 2005. He is currently a professor of Dept. of Computer Science at Yanbian University in China. His research interests are in the areas of Technology and Engineering, value assessment, financial analysis, copyright protection, digital rights management.

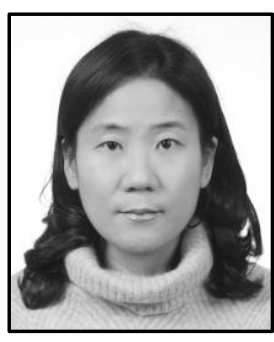

Hye Jeong Kim received the Ph.D. degree from KookMin University, major in Business Administration in 2006. She is currently a professor of Dept. of Operations Management at Kyonggi University in Korea. She is also a Principal Researcher at Institute, Human Resource Development Institute of Korea. She research interests are in the areas of Technology and Engineering, Production /Operations Management, Quality Management. 